\title{
Shaping Destination Image and Identity: Insights for Arab Tourism at the Gold
}

\author{
Coast, Australia
}

\section{INTRODUCTION}

Tourism marketing and the shaping of destination image is critically important, playing an integral role in influencing the perceptions and behaviour of tourists (Echtner and Ritchie, 2003; Hall, 2003). Effective tourism marketing not only lures tourists to a destination, it also sets appropriate expectations of the experiences available (Kozak, 2002). As such, destinations make extensive efforts to create, establish and defend a market and brand position (Siri, 2009). Previous studies have identified that the success of tourism marketing lies in finding an appropriate match between a destination's projected brand / identity, and tourists' images of that destination (Echtner and Ritchie, 2003; Morgan and Pritchard, 2001; Tascia, Gartner and Cavusgil, 2007).

It is thus important to understand the sources of travel information and destination image, to determine how image is constructed, shaped and changed (Moyle \& Croy, 2009). It is thought that one's image of a destination develops based on both organic and induced travel information sources (Gartner, 1993; Stepchenkova and Morrison, 2006). Organic sources are those that do not have a vested interest in the promotion of a destination, and emerge from the individual's own experiences and interactions (eg., visits to a destination, others' experiences, schooling, films, books and novels). Induced sources, on the other hand, are those that are deliberately developed to promote and encourage visitation to a destination (eg., tourism marketing, travel media, travel websites and the Internet). Destination image research tends to focus on the individual's cognitive and psychological development of image, but much less on the role of induced sources; as Gartner (1989) acknowledged well over 25 years ago, "in the absence of actual visitation, destination images are formed through induced agents" ( $p$. 16).

Culture, nationality, religion and cultural background have also been identified to influence the way that images about destinations are created (Stepchenkova and Morrison, 2006). A difference in 'culture' may mean a variance between the habits, traditions, actions and ability to understand the marketing messages addressed to tourists (Reisinger, 2003). As such, marketing campaigns which reply on stereotypical national 'identities' may not resonate with 
many international markets and cultures (Winter \& Gallon, 2008). Comparative analyses of different countries' and nations' marketing sources become of interest here, and perhaps even more so in the era of rapidly-changing, web-based travel promotion (Stepchenkova and Morrison, 2006). As a tourism destination, Australia has been competitive for many decades on the global stage in attracting inbound tourists from a variety of countries and cultures (Moyle et al., 2013). While tourism marketing campaigns remain focussed on the key markets of New Zealand, China, the UK and the USA (Australian Bureau of Statistics, 2014), other markets are also being closely watched, including Indonesia, India and the 'Middle East'. Not substantial statistics, perhaps, when compared to other markets, but 96,000 Arab visitors travelled to Australia in 2011 (ABS, 2012). Despite the emerging inbound Arab market, little is known about how Australia is promoted to, or viewed by, the 'Arab world'. This is especially true of the Gold Coast in Queensland which, because of its renowned beaches, shopping and family-friendly apartment-style accommodation, is becoming a destination of choice for many Arab visitors (Michael, et al., 2011; Mick, 2007).

This paper presents the findings of an exploratory, mixed method study which sought to determine how destination image is shaped, created, and crafted (induced), within tourism marketing materials. The study draws on two empirical, 'induced' sources from the tourism supply-side: a comparative content analysis of both Australian and Arab online destination promotional materials, and qualitative interviews with key Gold Coast destination marketing organisations (DMOs). The study aims to provide insights into how destination image is effectively built, projected and 'branded' in the minds of potential Arab visitors, from both an Australian and Arab perspective. In doing so, the findings will contribute to the destination image literature by going beyond image merely as constructed in the minds of the individual/cognitive, towards a consideration of the induced influence that tourism marketers (in both the push and pull countries) have in shaping destination image.

\section{LITERATURE REVIEW}

\section{Destination Marketing, Branding and Image Creation}

For survival within the globally competitive tourism market, the portrayal of a unique identity for a destination is more critical than ever (Buhalis, 2000). One of the main challenges facing tourism marketers is making a brand clear and attractive, and easily identifiable by customers. Concomitant to this is the role of tourism and destination marketers in shaping a positive and clear image of a destination in tourists' minds (Anh, 2012). As image is 
normally only held in the minds of the consumer/tourist, destination marketing efforts can be influential in the creation of a holistic image; thus ameliorating 'false' perceptions tourists might have about a particular destination (Malkawi, 2008).

Destination image is considered to be one of the most important study areas in the tourism literature (Lopes, 2011), with research on the subject dating back to the 1970s and 1980s (Li and Stepchenkova, 2012). Destination image has been generally defined as the sum of beliefs, ideas and impressions that people have of a place (Echtner and Ritchie, 2003; Kotler, 2002), including potential visitors. More recently, destination image has been defined as all impressions and ideas, beliefs and feelings accumulated over time about a place (Esper and Rateike, 2010). Destination image has a significant impact on decision-making in tourism or travel, both prior to and during the visit. Tourists often have little idea about places not yet visited, and the pictures held by tourists of these places can have a significant impact on their selection of a destination (Govers et al., 2007). Engendering a genuine and positive image for a destination provides an increased opportunity for it to be selected by a tourist as a place to visit. Therefore, understanding the destination image and how it can be created can have a significant impact on how competitive a destination's position is in the tourism market (Hall, Croy \& Walker, 2003).

Important here are the sources that lead to the shaping of destination image. According to Gartner (1993), sources of information can be classified into primary or secondary sources. A primary information source is related to previous experience (ie, a past visit to the destination). Secondary information sources also play a vital role in helping to shape tourists' destination image, though their potential influence on the cognitive dimension of individuals. And, as outlined in the Introduction, these sources can also be organic, or induced (Gartner, 1993); it is the induced sources that are the focus of this paper. Effective 'shaping' of destination image contributes to improving the attractiveness of a destination and strengthens its ability to compete (Esper and Rateike, 2010; Gras, 2008; Kurguni, 2010). Understanding a tourist's cultural background is also important in developing tourism marketing strategies (Isaac, 2008). While a tourist's cultural group and nationality has been reported to affect their understanding and vision of a tourism destination, it also potentially influences the way tourists receive marketing messages, and hence their perception of the destination brand image (Turner, Reisinger, and McQuilkin, 2001). This may in turn affect their choice of tourist destination (Kay, 2009). Therefore, understanding the social and cultural background of tourists contributes to the development of effective marketing strategies (Reisinger and 
Turner, 1997). Successful marketing strategies display an appropriate image for a destination and attract tourists to the destination, and are formulated by understanding the impact of national cultures and religions on tourists (Reisinger and Turner, 2000).

\section{Arab Tourism}

The commonly termed 'Arab world' is both a geographical and political term used to describe a region that shares some similar elements of history, language and culture. The Arab world is generally thought to include 22 countries and is located at the junction of two continents: the southwest Asian continent and the continent of Africa (Briney, 2011). Generally, the Arab world is associated widely with the 'Middle East' and also the Gulf States. While recognising the diversity and complexity of 'Arab' culture, and not wanting to resort to generalisations about 'Arab' tourists or 'Arab' society, this paper - as does this special issue - explores tourism from the perspective of those common threads that bind together an Arabic culture.

To date, there has been scant attention paid by researchers towards the motivations and experiences of outbound tourists from Arab countries and the Middle East (Alghamdi, 2007; Michael and Beeton, 2007). However, there are a couple of notable exceptions. One such study was undertaken by Bogari, Crowther and Marr (2004), who examined both the 'push' and 'pull' factors for Saudi Arabian domestic tourists, and determined that cultural variables play a significant role in tourism motivation. Factor analysis revealed nine 'push' motivational categories, namely: cultural value, utilitarian, knowledge, social, economic, family togetherness, interest, relaxation, and convenience of facilities. There were nine 'pull' motivational categories that resulted from factor analysis (safety, activity, beach sports/activities, nature/ outdoor, historical/cultural, religious, budget, leisure, and upscale).

Although the Arab world has several potential tourism destinations of its own that are rich in cultural monuments, beaches and tourist resorts (Mustafa, 2010), more Arab tourists are choosing to visit foreign countries, particularly those in Europe, Asia, and until the millennium, the USA (Prayag \& Hosany, 2013). After the September 112001 terrorist attacks in the United States, however, the number of Arab tourists there decreased, and visitation to other countries like Australia increased. This occurred primarily due to difficulties passing through customs and visa obstacles, as well as some negative perceptions about Muslims in general (Al- amarneh and Steiner; Mick, 2007). At first, Arab tourists turned their interest to South-East Asian countries such as Malaysia and Singapore, both of 
which have Islam as a key religion. In Malaysia, despite the existence of other religions, Arab tourists can exercise their Islamic worship freely and peacefully (Mahameed, 2011). There are also existing facilities and services that suit Arab tourists specifically, such as prayer rooms or areas in hotels and halal food being freely available (Sulaiman, 2010).

More recently, the numbers of Arab tourists have been gradually increasing and their destination of choice has been expanding. For instance in 2010, 790,000 tourists from the Middle East spent $£ 101$ billion in Britain (Osaimi, 2011); while 123,000 tourists from the Gulf countries visited Switzerland, a 19.7 percent increase in Arab tourists to the region (Aljamosee, 2011). In the same year, the Tourism Authority of Singapore announced that the high numbers of visitors from the Middle East to Singapore increased by 21.23 percent, reaching nearly 55,000 visitors (Husseini, 2010).

While the type of tourism that appeals to Arab tourists varies, the most favoured types of activities have been reported to include entertainment, adventure and shopping (Ariffin and Hasim, 2009; Michael, et al., 2011). Leisure tourism is the most common among Arab tourists, where the main purpose of the holiday is entertainment and enjoyment (Firyaan, 2011). Generally, Arab tourists are seeking destinations that offer different kinds of water entertainment resorts or wilderness opportunities where they can enjoy family, fun and entertainment. Importantly, Arabs usually travel with their family, preferring to rent private cars rather than use public transport, and stay at hotels that are equipped with interconnected rooms and/or suites or apartments (Mick, 2007). Shopping, however, is perhaps the most popular and desired tourist activity among Arabs (Alsheikh, 2006). Overall, the level of spending by Arabs is relatively high (Alganam, 2011), and they are generally viewed as a high-yield and coveted tourism market.

\section{Arab Tourism, Destination Marketing and the Gold Coast}

The Gold Coast is a beachside tourist destination located in the southeast of Queensland, Australia. The Gold Coast is situated about an hour's driving distance south from Brisbane, the state's capital, and includes around 70 kilometres of beach stretching along the southeast corner of the state (West and Bayne, 2002); at its centre is the renowned 'Surfers Paradise', the key shopping and beach hub of the Gold Coast. The Gold Coast's subtropical climate offers warm weather for most of the year, which is ideal for swimming, surfing, and other outdoor activities, however the area is also known for its significant natural features, 
particularly the bordering hinterland nature reserves, national parks and World Heritage rainforest (Dredge and Jamal, 2013).

The late 1990s and early 2000s were a turning point in Gold Coast's destination marketing history, with significant rebranding efforts to reinvigorate tiring facilities and accommodation, and in particular to address the gap left by a sharp reduction in Japanese visitor numbers after the Asian economic crisis (Pike, 2004). In 2000, Gold Coast Tourism, the area's local destination management organisation, created one of its key destination brands: 'The Coast with the Most'. There was general dissatisfaction with the results of this campaign, and a new brand was launched in November, 2004. The successful 'Very GC' slogan was created to mark a new direction for this destination with a higher level of sophistication (Pike, 2012). In order to refresh the Gold Coast's image yet again, its most recent brand, created in 2010, is 'Gold Coast: Famous For Fun'.

The Gold Coast has been heavily dependent on tourism for many decades (McLennan, Ritchie, Ruhanen and Moyle, 2013), with the sector now considered to be one of the largest generators of economic activity and employment in the city (West and Bayne, 2002); it is estimated that tourism to the Gold Coast is worth $\$ 4.6$ billion dollars to the economy, and a contributor of 30000 local jobs (Gold Coast Tourism, 2012). Domestic tourism is still the major contributor of visitation to the Gold Coast, with around 3.4 million domestic overnight visits, and 7 million domestic daytrip visits in 2011 (Gold Coast Tourism, 2012). In 2011, 747000 international visitors came to the Gold Coast, making it a smaller, but still significant, market for this beachside city; key international inbound markets are New Zealand, countries in Western Europe, China and Japan.

Arab tourists are a relatively new market to Queensland and the Gold Coast, but they are now actively targeted and marketed to by Australian and Queensland DMOs, given the high-yield nature of their spending. One study has estimated that about 15,000 visitors from the Middle East were spending $\$ 78$ million on the Gold Coast each year, compared with 114,000 Chinese tourists spending \$67 million. This makes the Middle East tourist group the largest spending group per capita on the Gold Coast (Meers, 2011). Tourists to Queensland from the Gulf States in particular (notably UAE and Qatar) saw a rise in the first decade of the 2000s, due in part to the events of September 11 described above, as well as new partnerships with airlines such as Emirates. Three flights land in Brisbane each week, and most Arab tourists then head south to the Gold Coast. Queensland and the Gold Coast are viewed as comparatively safe places to visit for Arab tourists; the Gold Coast in particular is popular for 
its outdoor beachside, family fun atmosphere, its shopping and its apartment-style holiday living (Michael, et al., 2011; Mick, 2007). In some ways, the Gold Coast and Arabic culture seem an unusual mix: the beachside destination is (in)famous for its sun, sand, sex and party atmosphere, known for its bikini-clad 'meter maids' and lively nightlife. None of this seems analogous to attracting an Arab market. However, in August 2011 a new advertisement for Islamic people was introduced, with some success. This advertisement, called 'Marhaba! Welcome to Australia's Gold Coast' (Tourism Queensland, 2011), focused on some of the habits of Muslims in the month of Ramadan that falls in August in this year, and highlighted the most important sites for Halal restaurants in this city. This advertisement sought to attract many Muslims to visit the Gold Coast during this religious month.

Though the number of Arab outbound visitors is increasing (Keating, 2010), and there is some evidence of Gold Coast service providers catering to Arab tourists' needs (Mick, 2007), there is still a limited understanding of how destinations can best market to and cater for Arab visitors. While the numbers of tourists to Australia from Arab countries and the Gulf States are comparatively small, they are a high-yield market and of growing importance for certain destinations like the Gold Coast. As discussed at the outset, this paper provides important insights into how both Australian and Arab destination marketing materials are currently projecting the Gold Coast to potential Arab visitors, and therefore influencing destination image.

\section{METHOD}

This study employed an exploratory, mixed method approach, drawing on both qualitative and quantitative methods. An inductive, 'grounded' approach to the study and its analysis was adopted, and in line with the exploratory intent (Jennings, 2010). That is, rather than set out with an explicit and overt theoretical framework, the study was informed by literature and theory on destination image, marketing and branding, aiming to inductively explore, through content analysis and interviews, how the Gold Coast and its identity was currently being projected and promoted. It was anticipated that these findings could then be followed up with future research to 'test' their applicability, and how the image is actually described and experienced by the Arab tourists themselves. As explained previously, this study focuses on the identity/supply side of destination marketing, and how this plays in role in shaping 
destination image for potential Arab tourists to Australia. It does not test or measure tourists' image.

Two sequential stages of research were implemented. The first stage focused on a quantitative content analysis of Australian and Arab tourism marketing websites to compare and contrast the representation/image of the Gold Coast. The second stage conducted indepth, semi-structured interviews with two key professionals from the DMOs directly responsible for marketing the Gold Coast to Arab visitors, namely Gold Coast Tourism and Tourism Queensland.

The content analysis was based on an approach by Pavlović and Belullo (2007), where the following steps were utilised:

I. Identify the most frequently used words describing the Gold Coast as a tourism destination on Australian tourism-related websites, and compare them with online Arab websites.

II. Identify the most frequently used visual information on Australian tourism-related websites, and compare them with the online Arab websites.

III. Examine of the similarities and/or differences between the image of the Gold Coast portrayed by Australian tourism websites with the image promoted by Arab websites.

Three Australian DMO websites were purposefully selected due to their responsibility for promoting tourism to Australia and the Gold Coast, namely Tourism Australia (TA), Tourism Queensland (TQ) and Gold Coast Tourism (GCT). For the Arabic websites, it was not possible to locate equivalent Arabic DMO websites with an Australian focus, so instead we visited a number of key Arab travel websites using the search headings of 'Gold Coast as tourist destination', 'Surfers Paradise', 'Australia destination'. A sample of 10 websites was strategically selected from those that were popular with Arab tourists and provided key information about the Gold Coast as a tourist destination. These websites were classified into three categories: a total of 3 travel blog websites, 4 online travel magazine websites and 3 travel trade websites. The first author is from an Arabic country, and could translate the results into English. Both narrative and visual information was analysed through content analysis. Building on a similar approach applied in previous studies (Day et al., 2002; Mackay and Fesenmaier, 2000; Stepchenkova and Morrison, 2006), the information being analysed was displayed and compared according to the most frequently used words and images for each website. 


\section{*INSERT TABLE 1 ABOUT HERE*}

For the interviews, questions were derived from a review of literature on destination marketing, branding and image, and drew from previous studies on Arab tourism. The interview guide was structured into three parts. The first part focused on the destination image of the Gold Coast; the second part on participants' knowledge of the Arab market, and the third part solicited information on marketing to Arab visitors.

Interviewees were selected through a purposeful sampling method, with respondents targeted from the two relevant DMOs. Tourism Queensland is the DMO for the state of Queensland, while Gold Coast Tourism is a local DMO, responsible for promoting tourism to Gold Coast. A purposive sample of two senior informants was selected to participate in the interviews, one from each organisation. The key selection criterion was that interviewees had to play a key role in the marketing of the Gold Coast to Arab visitors. The interviews took place at respondents' place of work early in 2012, with each lasting approximately one hour.

\section{RESULTS}

\section{Website Analysis}

How Australian websites project the Gold Coast

To analyse the textual element of the websites, web pages were browsed manually in the three Australian websites. Words were combined with the same meaning or with similar meanings under the one heading. For instance, Sea World and Dreamworld (theme parks) were both categorised as 'entertainment'. Table 2 shows the rank of the each keyword frequency in each of the Australian DMO websites.

\section{*INSERT TABLE 2 ABOUT HERE*}

This table shows that for Tourism Australia, the words used most frequently to describe the Gold Coast centred on a variety of entertainment places, particularly theme parks. By contrast, Tourism Queensland focuses its wording much more on accommodation. Here the 
phrases of Gold Coast accommodation is repeated several times in different phrases such as:

"Choosing from the amazing range of accommodation on the Gold Coast adds to the fun of your holiday" and "The five star resort offers a bird's eye view of the beaches from a towering high-rise". In the cases of both TA and TQ, the 'beach' was not ranked first or second in terms of the most frequently promoted concepts.

The Gold Coast Tourism website had a greater explanation about the attractiveness of the city, and the beach in particular, especially the famous Surfers Paradise. Here the advertisements of these attractions used many of the phrases such as "the iconic Surfers Paradise beach to the sophisticated dining precincts of Main Beach and Broad Beach", "The world-famous Surfers Paradise beach and breathtaking skyline remains a major draw card for millions of Gold Coast visitors each year", "green Hinterland, there's a new experience waiting for you", "world-renowned beaches and year-round sunshine", "a destination which is as scenic and peaceful" and "Surfers Paradise encapsulates all of the energy and excitement that only a unique and evolving location by the sea can offer".

Table 3 shows the frequency of the top five keyword categories across all Australian DMO websites. The most frequent was for 'Accommodation' (33.96\%), where a variety of luxury accommodation was displayed, followed by the 'Natural Environment' (24.52\%). 'Beaches' was the third most frequently used word (20.75\%) in the Australian DMO sites. 'Entertainment' was the fourth most frequently used word theme (15.09\%), where there were many mentions given to theme parks such as Dreamworld and Sea World. The least frequent keyword was for 'Shopping' or 'Shopping Centres' (5.66\%).

\section{*INSERT TABLE 3 ABOUT HERE*}

Images and pictures on the three Australian DMO websites were also analysed. The most frequent images from these websites were collected and categorised into the five categories. Table 4 shows the rank and percentages of these categories.

\section{*INSERT TABLE 4 ABOUT HERE*}

Table 4 demonstrates that the images of 'Accommodation' at the Gold Coast have taken the forefront on all of websites, which represented 48.81 percent. Images of the 'Natural 
Environment' (excluding beaches) took second place (23.24\%), and 'Beach' images ranked third (at 15.77\%), with images of 'Entertainment' places ranked fourth (6.11\%). Finally, images of 'Shopping' or 'Shopping Centres' ranked fifth and last at 6.05 percent. Thus, the majority of images related to the variety of accommodation, such as private villas, luxurious hotels and motels, a self-contained apartment, farmstay, and camping and caravans. There were more visual images of the natural environment (landscape, pictures of koalas and kangaroos, and National Parks).

\section{How Arab websites project the Gold Coast}

Using a similar content analysis approach, the analysis of the Arab tourism websites revealed six keyword themes that were mentioned either directly or by implication in the ten sites were selected, namely 'Beaches', 'Shopping Centres', 'Environment', 'Accommodation', 'Entertainment' and 'Weather'. The frequency rate for each keyword in all categories was calculated and these were used as a distance measure among the frequently occurring words (see Table 5). 'Beaches' and 'Shopping Centres' were clearly the most important attractions that were mentioned in all of ten Arab websites.

\section{*INSERT TABLE 5 ABOUT HERE*}

The imagery analysis on the 10 Arab websites revealed that the most frequent images on all sample Arab websites were 'Shopping' or 'Shopping Centres' images (30.68\%), followed by 'Accommodation' images (27.8\%) (See Table 6). Images of 'Beaches' and the 'Environment' both reached 14.2 percent, with pictures of 'Entertainment' at 13.1 percent. From this it can be demonstrated that the most frequent images were shopping centres, various hotels and a beautiful beach. However, by contrast, there were few images related to its environment and entertainment.

\section{*INSERT TABLE 6 ABOUT HERE*}

\section{Interviews}

The interviewees from both Tourism Queensland and Gold Coast Tourism, perhaps not surprisingly, reflected the current branding campaign of 'Gold Coast: Famous for Fun', 
emphasising attractions such as activity-based tourism, beaches, shopping and familybased leisure and theme parks:

The Gold Coast markets itself as a family friendly destination. This brand makes the Gold Coast a suitable destination for those who travel with family or with a group. In short, it is suitable for any age (children, youth and elderly people) ('John', TQ).

This brand image means that the visitors can enjoy their holidays in the Gold Coast attractions. There are many fun places to experience. In addition it is a big deal for their holiday, like beaches and theme parks... . The Gold Coast is a diversity destination, since there many places to visit such as different theme parks, natural environment of rainforest and beaches' ('Peter', GCT).

According to the two respondents, what differentiates the Gold Coast from other destinations are its beaches, the weather, as well as the rainforest and diversity of theme parks. The presence of this combination of unique features, they argue, distinguishes the Gold Coast from all other tourist destinations in Australia.

Both TQ and GCT discussed active marketing and campaigns for targeting the Arab tourist at the Gold Coast, and noted some positive growth rates associated with this. The interview participants considered the most important feature attracting Arab tourists to the Gold Coast's image as a family friendly and fun place, aligning with the current branding campaign. Both TQ and GCT have the ability to communicate to potential visitors from Arabic countries through the use of effective strategies to promote the Gold Coast, and to Arab Gulf countries in particular. 'John' (TQ) referred to some specific strategies, such as:

Working closely with their office in Dubai: airlines travel to that area and travel agencies are there. In addition they use the web to contact Arab countries, where they use facebook for Arab Gulf countries. For example they have provided a competition in English language, which was designed to gain an understanding of Arabian tourists' needs. There were 25,000 people participating in this competition, most of them from UAE, Saudi Arabia, Qatar and Bahrain.

Moreover, 'Peter' described how GCT recently invited Arab media to visit tourist places at the Gold Coast and a Ramadan dinner. As Peter also noted, understanding these unique 
cultural aspects were important in meeting Arab tourists' needs: 'Culture has a high effect on Arabian tourists because the culture is one of the important keys for this market. Ramadan is one example for that, where tourism marketers have to understand Arab tourists' behaviour in this month and their needs'.

Further, participants were asked to describe the characteristics of Arab tourists coming to the Gold Coast. 'John' from TQ indicated that 'The best characteristic of the Arab tourist traffic is high tourism yield because Arab tourists stay a long time, sometimes 30 days, and they have a higher spending level, when they send for their meals, accommodation and visiting places. 'Peter' agreed, citing the most important characteristics of Arab tourists as the high level of spending and long length of stay, and added their desire and propensity for familyfriendly accommodation and highly active itineraries:

Arab tourists prefer to travel with a large group as a family or multiple families, also they like to stay at apartments because they are better for the big family and the long stay... Arab tourists like to have a busy schedule where they like to visit many places and stay active all the time.

Both DMO representatives felt that it was these characteristics that made the Arab market different from others, and noted a need to develop appropriate offerings that met their needs and attracted more of them, in order to take advantage of their high spending. In addition, TQ and GCT both indicated that the most important factors affecting Arab tourist traffic to the Gold Coast were the month of Ramadan and the role of airlines and air connections.

We've been working with Arab market for 15 years. ... Important factors that have influence on Arab tourists flow are Ramadan month and airlines. Also the long trip between Arab countries and Australia affect their traffic coming to the Gold Coast....popular airlines used by Arab tourists are Etihad Airways, Emirates Airline, Qatar and Malaysian Airways. ('John', TQ)

Although they had special offers and advertisements for the Ramadan month in the Hilton hotel (dinner time), the numbers of Arab tourists decreased this year. Also, Arab tourists like to stay for a long time, but the Ramadan month became in the middle of the summer season in the Middle East region in this year, thereby this month comes at the middle of their holiday. ('Peter', GCT) 
The most popular airlines used by Arab tourists are Emirates, Qatar and Malaysia. Owing to the long distance between the Arab region and Australia, some of these airplanes take transit stops in some places, which led to extend the time of travel and the length of these trips: 'The high value of the Australian dollar has effect on flow of Arab tourists. Also, Arab tourists prefer to go to Europe countries for holiday due to shorter travel' (Peter, GC Tourism).

Both TQ and GCT representatives believed there was a requirement for some special needs and services for the Arabic market, such as prayer rooms in the accommodations and parks, Halal food, availability of mosques and multi-room family apartments. As 'John' from TQ revealed:

Prayer rooms are one of the important needs of Arab tourists, therefore some accommodation and theme parks at the Gold Coast are now providing these rooms. This in addition to Halal food - some hotels are now looking for Halal food for Arab tourists. ...the [X] Hotel sometimes provides a special bus to take Arab visitors to the Gold Coast mosque every Friday in order to do their prayers as well as provides family suites which have two or three bedrooms.

\section{DISCUSSION}

This paper sought to uncover how the Gold Coast was projected in both Australian and Arab online marketing materials, and through promotional efforts of relevant DMOs. This paper also sought to analyse if the perceived image of the Gold Coast on key Arab websites corresponded with the promoted image by key DMO websites responsible for promoting the destination to the Arab world: namely, Tourism Australia, Tourism Queensland and Gold Coast Tourism. As was shown for the Australian DMO websites, the most common themes of the Gold Coast attractions were accommodation, and the natural environment. Surprisingly, beaches did not rate as highly on the Australian sites as might be expected in this destination known for its long coast and surfing culture; indeed, beaches are often an essential part of the image of a coastal destination (Garcia et al, 2004).

Accordingly, it was interesting to note that although both of Arabic and Australian websites mentioned and featured similar attractions at the Gold Coast, there were slight differences about the important attractions of this city. In the main, Australian tourism websites showcased the variety of accommodation and the natural environment as key attractions, whereas Arab websites indicated the beach and shopping centres as main attractions in this 
city. If we are to take the Arab websites as an indication of how Arab tourists form their image, potentially there may be a discrepancy between the identity (and image projected/induced) of the Gold Coast and the image held in the minds of the tourist. This conclusion is similar to the findings of Knape and Lundell (2011) who also found that although Gothenburg's identity was fairly strong, there were some differences when compared with its measured image (Knape \& Lundell, 2011). Stepchenkova and Morrison (2006) also found significant differences between how Russian and American Internet sources projected the image of Russia. Tourism marketers should take into account these differences when developing their marketing strategies that target the Arab market.

Interviews with key informants also revealed that the relevant DMOs feel the 'Gold Coast: Famous for Fun' campaign is a fitting identity that should resonate with all tourists, including Arab tourists. To effectively build awareness about the destination through its brand, one destination must be distinguished from the other, in terms of its image and activities and the benefits each one offers (Chen \& Pan, 2006). The Arab websites emphasise the beach more than do the Australian, state and local DMOs, and entertainment did not rate as highly as the need for beaches, shopping and accommodation. Moreover, the study found that both the local (GCT) and state (TQ) DMOs have attempted to understand the Arab tourist market at the Gold Coast, where they have been working with Arab nations for around fifteen years. In accordance with interview respondents, despite the overall increase in Arabs travelling abroad, there are seasonal variations in visiting, primarily due to the date of Ramadan month. This is similar to Mat et al., (2009) who found that Malaysia is targeting Arabic tourists due to the growth in Arab visitors travelling abroad and the high yield of the Arab market (Mat et al., 2009). The results revealed that TQ and GCT collected information about Arab tourists' behaviour and characteristics.

Results of the interviews identified many characteristics that distinguish Arab tourists from those from other countries, including high expenditures, length of stay, travelling with large groups, wishing to visit different places and staying active all the time; all factors that have been identified in previous research (Ariffin and Hashim, 2009; Mick, 2007). The interviews revealed there need to be specific strategies employed to target Arab tourists to Queensland and the Gold Coast. Concerted efforts and good working relationships between DMOs and strategic tourism organisations in the Arab world were of key importance. These strategies included working closely with partners in Dubai, working with airlines that travel to this area, the use of the Internet to establish contact with Arab countries, and inviting Arab media 
representatives to visit tourist places at the Gold Coast. Such strategies were helpful in building awareness of Australia to Arab tourists. Implementing targeted strategies for each market using culture as a key segmentation tool can not only help to attract tourists, but assist DMOs to understand the special needs of various cultures in the destination.

Both the Queensland DMOs spoke of the importance of special needs and services in relation to the Arab tourist market, such as prayer rooms in accommodation and parking areas, halal food and availability of mosques and family suites that had two or three bedrooms in the hotels. Therefore, when a destination is able to meet the needs of a specific cultural tourist groups, not only will it be perceived as attractive, but a realistic option that meets tourists everyday needs and lifestyle requirements. This resonates with the literature, which has shown that knowledge of tourists' cultural background is of critical importance for marketing managers (Torres, 2006). This finding is similar to that of Reisinger (2009) who found that culture has an impact on tourism planning and indicated the importance of providing special strategies for each market, where different tourists have different needs, and they should be satisfied by a variety of different ways (Reisinger, 2009).

\section{CONCLUSION}

In the 21 st century there has been an increase in the number of Arab tourists visiting various countries throughout the world, including Australia. Yet very little academic research has been carried out with regards to how Western destinations can appropriately market to Arab visitors, and how destinations can be adequately prepared for a more mobile Arab population. Consequently, this paper sought to provide insights into how the Gold Coast, in Australia marketed its core product to Arab visitors, as well as to compare the projected and perceived image of the Gold Coast to Arab visitors. The image and the identity of destination have a significant impact on the effectiveness of tourism marketing strategies. Therefore, understanding how the tourism industry currently projects the identity of the Gold Coast is crucial for understanding how to effectively meet and satisfy the images, expectations and perceptions of Arab tourists. Where a gap exists between the image and the identity, this can lead to an undesirable market position (Saraniemi, 2011; Stepchenkova and Morrison, 2006).

Destination marketers need to be aware of any ideas and images that might not hold 'true' in the eyes of the tourist. This result is supported by interviews and content analysis results. Further research now needs to test these findings presented in this paper, by studying the Arab tourists themselves and their primary/organic imagery; to effectively target the Arab 
market, Australian destination marketers need to shape and build strong image, identity and brand, and in doing so, reduce any potential negative destination images that current and potential Arab tourists might hold.

A core contribution of this research is a more nuanced understanding of the importance of culture in tourism marketing from a supply side perspective. This, in turn, can be used to facilitate more effective destination marketing of Australia as a tourism destination in Arab countries. Understanding Arab culture and Arab tourists' perceptions and motivations can assist tourism businesses to create and deliver successful tourism products, especially at the regional level. Future research should focus on understanding service quality perception. This will provide marketers with a better picture of customers, from their motivation profiles to behaviour that might be useful in the targeting or development of a promotional strategy.

\section{REFERENCES}

Alganam, A. (2011), “An increase in Switzerland's tourists from the Gulf by 13\%”, Alriyadh Newspaper. 22 April.

Alghamdi, A. (2007), "Explicit and implicit motivation towards outbound tourism: A study of Saudi tourists", (Unpublished doctoral dissertation), The University of Glasgow, Glasgow, UK.

Al-Hamarneh, A., and Steiner, C. (2004). "Islamic tourism: Rethinking strategies of tourism development in the Arab World after September 11'2001", Comparative Studies of South Asia, Africa and the Middle East, Vol. 24, No. 1, pp. 173-182.

Aljamosee, M. (2011), "Switzerland ... Magic snow impressing gulf: Kuwaitis are second in tourism from the regional countries." Alrai Newspaper

Alsheikh, E. (2006), "Survey: Arabs travel for shopping first", Middle East: Arab International Newspaper, 26, March, p. 1.

Anh, P. (2012), "Identifying and improving the images of Vietnam as a tourism destination among Finnish tourists" (Unpublished Bacheloris dissertation), HAMK University of Applied Sciences, Valkeakoski, Finland.

Ariffin, A., and Hasim, M. (2009), "Marketing Malaysia to the Middle East Tourists: Towards a preferred inter-regional destination", Jurnal Antarabangsa Kajian Asia Barat International Journal of West Asian Stusies, Vol. 1, pp. 39-53.

Australia China Business Council (2012), "How China trade benefits Australian households", Australia China Business Council, Sydney, NSW, pp. 48. 
Australian Bureau of Stastistics (2012), "International tourism remains steady despite fragility in the global economy”, Australia's Quarterly Market Update, Vol. 8, Tourism Australia, Sydney.

Australian Bureau of Statistics (2014), "International tourism: Markets", available at http://www.tourism.australia.com/markets.aspx (accessed 25 September 2014).

Bogari, N., Crowther, G., and Marr, N. (2003), "Motivation for domestic tourism: A case study of The Kingdom of Saudi Arabia", Tourism Analysis, Vol. 8 Nos. 2-4, pp. 137-141.

Briney, A. (2011), "List of Arab States: List of the countries making up the Arab world", available at http://geography.about.com/od/lists/a/arab-countries.htm (accessed 1 December 2012).

Buhalis, D. (2000), "Marketing the competitive destination of the future", Tourism Management, Vol. 21, pp. 97-116.

Chen, N., and Pan, H. (2006), "Gothenburg's image as a tourism destination among typical tourists and sport tourists", (Unpublished Masters dissertation), Goteborg University, Goteborg, Sweden.

Day, J., Skidmore, S., and Koller, T. (2002), "Image selection in destination positioning: A new approach", Journal of Vacation Marketing, Vol. 8 No. 2, pp. 177-186.

Dredge, D., and Jamal, T. (2013), "Mobilities on the Gold Coast, Australia: Implications for destination governance and sustainable tourism", Journal of Sustainable Tourism, Vol. 21 No. 4, pp. 557-579.

Echtner, C., and Ritchie, B. (2003), "The meaning and measurement of destination image", The Journal of Tourism Studies, Vol. 14 No. 1, pp. 37-47.

Ekinci, Y. (2003), "From destination image to destination branding: An emerging area of Research", e-Review of Tourism Research (eRTR), Vol. 1 No. 2, pp. 21-24.

Esper, F. S., and Rateike, J. Á. (2010), "Tourism destination image and motivations: The Spanish perspective of Mexico", Journal of Travel \& Tourism Marketing, Vol 27, pp. 349360 .

Firyaan, K. (2011), "Favourite countries of the Middle East for Saudi Tourists, followed by Asia, Europe”, Riyadh Newspaper, 9 November, p. 1.

Gold Coast Tourism (2012), “Annual Report 2011/2012”. Gold Coast Tourism: Gold Coast.

Govers, R., Go, F., and Kumar, K. (2007), "Promoting tourism destination image", Journal of Travel Research, Vol. 46.

Hall, C. M., Croy, W. G., and Walker, R. (2003), "Imaging and branding the destination", In Hall, C. M. (Ed.), Introduction to Tourism: Dimensions and Issues, $4^{\text {th }}$ edn, Frenchs Forest, NSW, Australia, pp. 105-125.

Husseini, A. (2010), "Increase in the number of visitors from the Middle East to Singapore", Journal of Faris the Arabs, Vol. 1 No. 1, pp. 172-173. 
Isaac, R. (2008), "Understanding the behaviour of cultural tourists: Towards a classification of Dutch cultural tourists", (Unpublished Doctoral dissertation), The University of Groningen, Groningen, Holland.

Jennings, G. (2010), Tourism Research (2 ed.), John Wiley \& Sons Australia,.Milton, QLD, Australia.

Kay, P. (2009). "Cultural experience tourist motives dimensionality: A cross-cultural study", Journal of Hospitality Marketing \& Management, Vol. 18 No. 2-3, pp. 329-371.

Keating, J. (2010), “Gold Coast Corporation Annual Report 2009/2010” (pp. 25), Gold Coast. Australia: Gold Coast Corporation.

Kozak, M. (2002), "Comparative analysis of tourist motivations by nationality and destinations”, Tourism Management, Vol. 23 No. 3, pp. 221-232.

Li, X., \& Stepchenkova, S. (2012), "Chinese outbound tourists' destination image of America, Part I”, Journal of Travel Research, 5(3), pp. 250-266.

Lopes, S. (2011), "Destination image: Origins, developments and implications", PASOS. Revista de Turismo y Patrimonio Cultural, Vol. 9 No. 2, pp. 305-315.

Mackay, K., and Fesenmaier, D. (2000), “An exploration of cross-cultural destination image assessment", Journal of Travel Research, Vol. 38 No. 4, pp. 417-423.

Mahameed, K. (2011), "Confused: Years of political turmoil turns the tourism map", AlWatan, 1.

Malkawi, O. (2008), Principles of Marketing Tourism and Hotels. Warraq Foundation, Amman, Jordan.

Mat, A., Zakaria, H.-A., and Jusoff, K. (2009), "The importance of Arabic Language in the Malaysian tourism industry: Trends during 1999-2004", Canadian Social Science, Vol. 5, No. 4, pp. 12-17.

McLennan, C. J., Ruhanen, L. M., Ritchie, B. W. and Moyle, B. D. (2014). “An institutional assessment of three local government-level tourism destinations at different stages of the transformation process", Tourism Management, Vol. 41, 107-118.

Meers, D. (2011). “Arabs rather green side of Gold Coast”, News Gold Coast.

Michael, I., Armstrong, A., Badran, B., and King, B. (2011), "Dubai outbound tourism: An exploratory study of Emiratis and expatriates", Journal of Vacation Marketing, Vol. 17 No. 1, pp. 83-91.

Michael, N., and Beeton, S. (2007), "Exploring the cultural transferability of western-derived tourist motivation theories in Arabic culture: A preliminary discussion", Paper presented at CAUTHE Conference, February 2007, Sydney, Australia.

Mick, H. (2007), “Arab tourists flocking to Gold Coast”, ABC News, 29 September 2007, available at: http://www.abc.net.au/news/2007-09-29/arab-tourists-flocking-to-goldcoast/684458 (accessed 20 September 2013). 
Morgan, N., and Pritchard, A. (2001), Advertising in Tourism and Leisure, ButterworthHeinemann, Oxford, UK.

Moyle, B. D. and Croy W. G. (2009). "Media in the Pre-Visit Stage of a Recreation Experience: Port Campbell National Park", Tourism Analysis, Vol. 14 No. 2, pp. 199-208.

Moyle, B. D, McLennan, C., Ruhanen, L. and Weiler, B. (2014). "Tracking the Concept of Sustainability in Australian Tourism Policy and Planning Documents", Journal of Sustainable Tourism, Vol. 22 No. 7, pp. 1037-1051

Mustafa, M. H. (2010), "Tourism and globalization in the Arab World", International Journal of Business and Social Science, Vol. 1 No. 1, pp. 37-48.

Osaimi, N. (2011), "London: Gulf Tourists Stay Longer and Spend More", The Middle East, p. 1.

Pike, S. (2004), "Destination brand positioning slogans: Towards the development of a set of accountability criteria", Acta Touristica, Vol 16 No. 2, pp. 102-124.

Pike, S. (2012), Destination Marketing, Taylor \& Francis, New York, USA.

Prayag, G., and Hosany, S. (2013), "When Middle East meets West: Understanding the motives and perceptions of young tourists from United Arab Emirates", Tourism Management, Vol. 40, pp. 35-45.

Reisinger, Y. (2009), International Tourism: Cultures and Behavior. ButterworthHeinemann. Oxford, UK:

Reisinger, Y., and Turner, L. (1997), "Cross-cultural differences in tourism: Indonesian tourists in Australia", Tourism Management, Vol. 18 No. 3, pp. 139-147.

Reisinger, Y., and Turner, L. (2000), "Japanese tourism satisfaction: Gold Coast versus Hawaii”, Journal of Vacation Marketing, Vol. 6 No. 4, pp. 299-317.

Reisinger, Y., \& Turner, L. (2003), Cross-Cultural behaviour in tourism: Concepts and Analysis, Butterworth-Heinemann, Oxford.

Siri, R. (2009), "Indian tourists' motivation, perception, and satisfaction of Bangkok, Thailand", (Unpublished Masters dissertation), University Of North Texas, University Of North Texas.

Stepchenkova, S., and Morrison, A. (2006), "The destination image of Russia: from the online induced perspective", Tourism Management, Vol. 27, pp. 943-956.

Sulaiman, H. (2010), " $8 \%$ Increase in The Number of Saudi Tourists This Summer, and 75 Countries Received Them” Al-Riyadh Newspaper, 22 October, pp. 1-2. 
Tascia, A. D. A., Gartner, W. C., \& Cavusgil, S. T. ( 2007), "Measurement of destination brand bias using a quasi-experimental design", Tourism Management, Vol. 28 No. 6, pp. 1529-1540.

Torres, G. (2006), “A cross-cultural comparison of ethical attitudes of marketing managers: Puerto Rico and the United States", (Unpublished Doctoral dissertation), Argosy University/ Sarasota, Argosy University/Sarasota, Florida.

Tourism Australia (2009), “Gold Coast, The Surfers Paradise”, available at: http://www.visitqueensland.com/iss/emerging-markets/regions/gold-coast/gold-coast_home.cfm.

Tourism Queensland (2011), "Mosques and Halal Restaurants", available at: http://www.visit-queensland.com/iss/emerging-markets/travel-info/mosques-and-halalrestaurants.cfm. (accessed 5 April 2014).

Turner, L., Reisinger, Y., and McQuilken, L. (2001), "How cultural differences cause dimensions of tourism satisfaction", Journal of Travel \& Tourism Marketing, Vol. 11 No. 1, pp. 79-101.

West, G., \& Bayne, B. (2002). "The Economic Impacts of Tourism on the Gold Coast”, In G. West \& B. Bayne (Eds.), Project Report (Gold Coast Tourism Visioning Project), Common Ground Publishing, Altona, Victoria, Australia.

Winter, C., and Gallon, S. (2008), "Exploring attitudes towards Tourism Australia's 'Where the bloody hell are you?' campaign”, Current Issues in Tourism, Vol. 11 No. 4, pp. 301-314. 


\section{Table 1: Australian Websites and Arab websites in Content Analysis}

\begin{tabular}{|l|l|}
\hline Australian Websites & Arab websites \\
\hline Tourism Australia & Travel Blogs \\
http://www.tourism.australia.com & $-\quad$ Alwahoob for tourism \\
Tourism Queensland & $-\quad$ Maktob for Travel \\
http://www.queenslandholidays.com.au & http://www.alwahoob.com. \\
& http://travel.maktoob.com. \\
Gold Coast Tourism & http://www.almethaqalaraby.net. \\
& http:/www.masrawysat.com \\
http://www.visitgoldcoast.com & Online Travel Magazines: \\
& $-\quad$ Altayyar Group \\
& $-\quad$ Zahma Magazin \\
& $-\quad$ Alittihad Magazin \\
& \\
& http://www.altayyargroup.com. \\
& http://forum.z7mh.com. \\
& http://www.alittihad.ae/columnsdetails.ph \\
& Travel Trade Websites: \\
& $-\quad$ Sfari \\
& $-\quad$ Sawah \\
& \\
& http://www.sfari.com. \\
& http://www.sawah-mag.com. \\
\hline
\end{tabular}


Table 2: Most Frequent Keywords in Rank Order: Australian DMO Websites

\begin{tabular}{|l|l|l|l|}
\hline Rank & Tourism Australia & Tourism Queensland & Gold Coast Tourism \\
\hline 1 & Entertainment & Accommodation & Beach \\
\hline 2 & Natural Environment & Natural Environment & Natural Environment \\
\hline 3 & Beach / Accommodation & Entertainment & Accommodation \\
\hline 4 & Shopping centres & Beach & Entertainment \\
\hline 5 & N/A & Shopping centres & Shopping centres \\
\hline
\end{tabular}


Table 3: Frequency Rates of Keywords:All Australian DMO Websites

\begin{tabular}{|l|c|c|}
\hline Keywords & Count (n) & \% \\
\hline Accommodation & 72 & $33.96 \%$ \\
\hline Natural Environment & 52 & $24.52 \%$ \\
\hline Beaches & 44 & $20.75 \%$ \\
\hline Entertainment & 32 & $15.09 \%$ \\
\hline Shopping Centres & 12 & $5.66 \%$ \\
\hline Total & $\mathbf{2 1 2}$ & $\mathbf{1 0 0 \%}$ \\
\hline
\end{tabular}


Table 4: Key Imagesfrom Australian DMO Websites

\begin{tabular}{|l|c|c|c|c|c|c|c|c|}
\hline Image themes & \multicolumn{2}{|c|}{$\begin{array}{c}\text { Tourism } \\
\text { Australia }\end{array}$} & \multicolumn{2}{c|}{$\begin{array}{c}\text { Tourism } \\
\text { Queensland }\end{array}$} & \multicolumn{2}{c|}{$\begin{array}{c}\text { Gold Coast } \\
\text { Tourism }\end{array}$} & \multicolumn{2}{|c|}{ Total } \\
& $\mathbf{n}$ & $\mathbf{\%}$ & $\mathbf{n}$ & $\mathbf{\%}$ & $\mathbf{n}$ & $\mathbf{\%}$ & $\mathbf{n}$ & $\%$ \\
\hline Accommodation & 13 & $39.39 \%$ & 347 & $49.78 \%$ & 358 & $48.31 \%$ & $\mathbf{7 1 8}$ & $\mathbf{4 8 . 8 1 \%}$ \\
\hline $\begin{array}{l}\text { Natural } \\
\text { Environment }\end{array}$ & 9 & $27.27 \%$ & 163 & $23.38 \%$ & 170 & $22.94 \%$ & $\mathbf{3 4 2}$ & $\mathbf{2 3 . 2 4 \%}$ \\
\hline Beaches & 11 & $33.33 \%$ & 101 & $14.49 \%$ & 120 & $16.19 \%$ & $\mathbf{2 3 2}$ & $\mathbf{1 5 . 7 7 \%}$ \\
\hline Entertainment & - & - & 42 & $6.02 \%$ & 48 & $6.47 \%$ & $\mathbf{9 0}$ & $\mathbf{6 . 1 1 \%}$ \\
\hline $\begin{array}{l}\text { Shopping } \\
\text { Centres }\end{array}$ & - & - & 44 & $6.31 \%$ & 45 & $6.07 \%$ & $\mathbf{8 9}$ & $\mathbf{6 . 0 5 \%}$ \\
\hline Total & $\mathbf{3 3}$ & $\mathbf{1 0 0 \%}$ & $\mathbf{6 9 7}$ & $\mathbf{1 0 0 \%}$ & $\mathbf{7 4 1}$ & $\mathbf{1 0 0 \%}$ & $\mathbf{1 4 7 1}$ & $\mathbf{1 0 0 \%}$ \\
\hline
\end{tabular}


Table 5: Frequency Rates of Keywords: Arab Websites

\begin{tabular}{|l|c|c|}
\hline Keywords & Count (n) & Percentages \\
\hline Beaches & 25 & $32.89 \%$ \\
\hline Shopping Centres & 20 & $26.31 \%$ \\
\hline Accommodation & 13 & $17.10 \%$ \\
\hline Entertainment & 9 & $11.84 \%$ \\
\hline Environment & 6 & $7.89 \%$ \\
\hline Weather & 3 & $3.94 \%$ \\
\hline Total & $\mathbf{7 6}$ & $\mathbf{1 0 0 \%}$ \\
\hline
\end{tabular}


Table 6: Key Images on Arab Websites

\begin{tabular}{|l|c|c|c|c|c|c|c|c|}
\hline Image themes & \multicolumn{2}{|c|}{ Blogs } & \multicolumn{2}{c|}{ Magazines } & \multicolumn{2}{c|}{ Trade } & \multicolumn{2}{c|}{ Total } \\
\hline & $\mathbf{n}$ & $\mathbf{\%}$ & $\mathbf{n}$ & $\mathbf{\%}$ & $\mathbf{n}$ & $\mathbf{\%}$ & $\mathbf{n}$ & $\%$ \\
\hline Shopping centres & 5 & $11.36 \%$ & 3 & $6.81 \%$ & 46 & $51.68 \%$ & $\mathbf{5 4}$ & $\mathbf{3 0 . 6 8 \%}$ \\
\hline Accommodation & 17 & $38.63 \%$ & 12 & $27.27 \%$ & 20 & $22.47 \%$ & $\mathbf{4 9}$ & $\mathbf{2 7 . 8 4 \%}$ \\
\hline Beaches & 8 & $18.18 \%$ & 5 & $11.36 \%$ & 13 & $14.60 \%$ & $\mathbf{2 5}$ & $\mathbf{1 4 . 2 0 \%}$ \\
\hline Environment & 10 & 22.72 & 12 & $27.27 \%$ & 3 & $3.37 \%$ & $\mathbf{2 5}$ & $\mathbf{1 4 . 2 0 \%}$ \\
\hline Entertainment & 4 & 9.09 & 12 & $27.27 \%$ & 7 & $7.86 \%$ & $\mathbf{2 3}$ & $\mathbf{1 3 . 0 6 \%}$ \\
\hline Total & $\mathbf{4 4}$ & $\mathbf{1 0 0} \%$ & $\mathbf{4 4}$ & $\mathbf{1 0 0 \%}$ & $\mathbf{8 9}$ & $\mathbf{1 0 0 \%}$ & $\mathbf{1 7 6}$ & $\mathbf{1 0 0 \%}$ \\
\hline
\end{tabular}

